NBER WORKING PAPER SERIES

\author{
TESTS OF THREE PARITY \\ CONDITIONS: DISTINGUISHING \\ RISK PREMIA AND SYSTEMATIC \\ FORECAST ERRORS
}

Richard C. Marston

Working Paper No. 4923

\author{
NATIONAL BUREAU OF ECONOMIC RESEARCH \\ 1050 Massachusetts Avenue \\ Cambridge, MA 02138 \\ November 1994
}

The author appreciates the comments of seminar participants at the Bank of Norway, Kiel Institute, and New York University. He is grateful to Sanwa Bank and the Wharton School's Weiss Center for International Financial Research for financial support This paper is part of NBER's research program in International Finance and Macroeconomics. Any opinions expressed are those of the author and not those of the National Bureau of Economic Research.

(C) 1994 by Richard C. Marston. All rights reserved. Short sections of text, not to exceed two paragraphs, may be quoted without explicit permission provided that full credit, including () notice, is given to the source. 


\title{
TESTS OF THREE PARITY \\ CONDITIONS: DISTINGUISHING \\ RISK PREMIA AND SYSTEMATIC \\ FORECAST ERRORS
}

\begin{abstract}
Two explanations are given for why nominal or real retums differ across currencies: foreign exchange risk premia and systematic (rational) forecast errors. This study reexamines three parity conditions in international finance, uncovered interest parity, purchasing power parity, and real interest parity, to determine the relative importance of these two factors. The study develops joint tests of the three parity conditions by relating nominal and real interest differentials and inflation differentials to the same set of variables currently known to investors. The study tests parameter restrictions based on knowing that risk premiums only affect nominal and real interest differentials, but not inflation differentials, while systematic errors in forecasting exchange rates only affect nominal interest differentials and inflation differentials, but not real interest differentials.
\end{abstract}

Richard C. Marston

Wharton School

University of Pennsylvania

Philadelphia, PA 19104

and NBER 
Three parity conditions have preoccupied empirical researchers in international finance searching for the links between markets in different currencies: uncovered interest parity, purchasing power parity, and real interest parity. These parity conditions have been tested using a variety of methods. Uncovered interest parity has been rejected in most cases, but the two other parity conditions have fared much better. ${ }^{1}$ Two competing explanations have been offered to justify departures from uncovered interest parity: foreign exchange risk premia and systematic forecast errors, but it is difficult to distinguish empirically between these two explanations. By exanining the three parity conditions together, however, it should be possible to determine the relative importance of these two explanations since risk premia and forecast errors have different impacts on the other two parity conditions.

The study develops joint tests of the three parity conditions by relating nominal and real interest differentials and inflation differentials to the same set of variables currently known to investors. The tests consist of parameter restrictions based on knowing that risk premia only affect nominal and real interest differentials, but not inflation differentials, while systematic errors in forecasting exchange rates only affect nominal interest differentials and inflation differentials, but not real interest differentials.

${ }^{1}$ As explained below, conventional PPP has been rejected in most studies, but an expectational form of PPP has been more robust. 
The study examines interest differentials using two quite different sets of returns. Most studies of interest differentials have been confined to short term Eurocurrency markets or short term national money market instruments such as interbank rates. This study will examine one month Eurocurrency interest rates, but it will also examine bond yields using a new holding period series developed by Morgan Guaranty Trust. Although the MGT series begins only in 1985 , it has been extended back through the entire floating rate period beginning in 1973 using a methodology developed by Shiller (1979) for U.S. yields.

The study begins by discussing the link between real interest parity and the other two parity conditions. Then joint tests of the three parity conditions are described in detail. The last two sections of the paper apply these tests to one-month Eurocurrency rates and holding period yields on medium-term government bonds.

\section{A. Real Interest Parity Defined}

Real interest parity holds if the real interest rates faced by two different sets of investors or borrowers are equal. Many observers believe that real interest parity should hold as long as there are no barriers to trade in assets. Yet there is no set of agents willing and able to take advantage of deviations from real interest parity. To show that this is the case, I first define several real interest rates faced by firms in the American and foreign markets.

Consider an American firm that can borrow either in its own market or in country k's market. If the U.S. interest rate is given by $i_{A t}$ and the expected inflation rate by $\pi_{A t}$, then the real interest rate 
faced by the American firm borrowing in its own market is given by: ${ }^{2}$

$$
E_{t} r_{A l}=i_{A t}-\pi_{A t}
$$

This real interest rate is defined as the expected or ex ante cost of financing where the expectation is based on information available at time $t$. The American firm faces a different real interest rate if it borrows in the foreign market. If $i_{k t}$ is the interest rate in country $k$ and $\Delta x_{k t}$ is the expected rate of depreciation of country k's currency, ${ }^{3}$ then the real interest rate faced by the American firm in that market is:

$$
\mathrm{E}_{\mathrm{t}} \mathrm{r}_{\mathrm{Al}}^{*}=\left(\mathrm{i}_{\mathrm{kt}}-\Delta \mathrm{x}_{\mathrm{kt}}\right)-\pi_{\mathrm{Al}}
$$

Both real interest rates are deflated by the same expected inflation rate used to deflate any financing by this firm. If the firm were a multinational with major sales abroad, it might make sense to deflate by a weighted average of foreign and American inflation rates, but the same deflator should be used for both American and foreign financing.

2 All interest rates and other variables are expressed in continuously compounded form. Thus $i_{A t}$ is the continuously compounded American interest rate which is related to the simple American interest rate, $I_{A l}$, by the expression: $i_{A t}=\ln \left[1+I_{A t}\right]$. Similarly, $\pi_{A t}$ is the expected American inflation rate given by $E_{t}$ $\left[\ln \left(\mathrm{P}_{\mathrm{Al}+1} / \mathrm{P}_{\mathrm{Al}}\right)\right]$.

3 If $S_{k t}$ is the currency $k$ price of the dollar, then the expected rate of depreciation of currency $k$ is given by $\Delta x_{k t}=E_{t}\left(S_{k t+1} / S_{k t}\right)$. 
The two real interest rates faced by the American firm collapse to one if expected nominal returns are equal across currencies:

$$
i_{k t}=i_{A t}+\Delta x_{k t}
$$

This is the familar uncovered interest parity (UIP) condition which says that the interest rate in country $\mathrm{k}$ is equal to the expected nominal return (interest rate plus currency gain) from investing in the United States.

A firm from country $\mathrm{k}$ faces a separate set of real interest rates. The real interest costs faced by such a firm in its own market and in the American market are given by:

$$
\begin{aligned}
& E_{t} r_{k t}=i_{k t}-\pi_{k t} \\
& E_{t} r_{k t}^{*}=\left(i_{A t}+\Delta x_{k t}\right)-\pi_{k t}
\end{aligned}
$$

Both real interest costs are expressed in currency $\mathrm{k}$ before being deflated by the expected inflation rate in currency $k$. As in the American case, these costs are distinct unless UIP holds.

Using the real interest rates defined above, real interest parity (RIP) can be written as:

$$
E_{t} r_{A t}=E_{t} r_{k t} .
$$

That is, the real cost of financing for the American firm borrowing in its own market is equal to the real cost of financing for country k's 
firm borrowing in k's market. In a frequently-cited study, Adler and Lehmann (1983) argue that real interest parity is ensured by "financial arbitrage" in bonds. However, there is no single borrower (or investor) who compares these two real interest rates, so there is no direct arbitrage which ensures that (5) holds. An American firm, for example, may compare $E_{t} r_{A t}$ with $E_{t} r_{A t}^{*}$, but will not compare either real interest rate with $\mathrm{E}_{\mathbf{t}} \mathrm{r}_{\mathrm{kl}}{ }^{4}$

Real interest parity will hold under two conditions which are made apparent by decomposing the differential between the real interest rates as follows: 5

(6) $\mathrm{E}_{\mathrm{t}} \mathrm{r}_{\mathrm{kt}}-\mathrm{E}_{\mathrm{t}} \mathrm{r}_{\mathrm{At}}=\left[\mathrm{i}_{\mathrm{kt}}-\left(\mathrm{i}_{\mathrm{At}}+\Delta \mathrm{x}_{\mathrm{kt}}\right)\right]-\left[\pi_{\mathrm{kt}}-\left(\pi_{\mathrm{At}}+\Delta \mathrm{x}_{\mathrm{kt}}\right)\right]$.

The first term in parentheses is the uncovered (nominal) interest differential, while the second term is the expected deviation from purchasing power parity (PPP). This second expression says that expected rates of inflation are equal across currencies when expressed in a single currency or, alternatively, that expected rates of depreciation of currency $\mathrm{k}$ are equal to the expected inflation differential between the United States and country $k$. So real

${ }^{4}$ Real interest parity might be brought about indirectly by trade flows under the same conditions that equalize other factor prices, but it is doubtful that the researchers who have tested real interest parity had such an indirect mechanism in mind.

5 Several studies emphasize the link between the two underlying parity conditions and real interest parity including Mishkin (1984), Cumby and Obstfeld (1984), and Frankel (1986). 
interest parity must hold if (1) UIP holds and (2) the expectational form of PPP or "ex ante PPP" holds. Real interest parity does involve "financial arbitrage," but of nominal, not real, returns. The second condition involving ex ante PPP, however, is a condition involving goods markets, not financial markets. ${ }^{6}$

\section{B. Interpretation of Departures from the Three Parity Conditions}

Real interest parity is an ex ante concept involving expected rather than actual inflation. Since expected inflation rates are unobservable, so also are expected (or ex ante) real interest rates. What we can observe are ex post real interest rates defined by using actual inflation rates. Ex post real interest rates differ from expected real rates by forecast errors in predicting inflation rates, $\mu_{\mathrm{kt}}=\left(\Delta \mathrm{p}_{\mathbf{k t}}\right.$ $\left.\Delta \mathrm{p}_{\mathrm{At}}\right)-\left(\pi_{\mathrm{kt}}-\pi_{\mathrm{Al}}\right)^{7}$ It is useful to think of ex post real interest differentials as being attributable either to ex post differentials in nominal interest returns or PPP differentials or some combination of the two.

Consider first ex post deviations from uncovered interest

6 The sharp distinction between real interest rates facing domestic and foreign firms becomes blurred if both sets of firms are multinationals with worldwide sales (and even worldwide production). With increasingly integrated financial markets, it is the prices faced by firms which distinguish their real costs of financing from those of other firms. Most firms in the G-5 countries, however, sell more to their own markets than do foreign firms, so domestic prices matter more to the domestic firm than to foreign firms. / $\mathrm{P}_{\mathrm{kl}} \mathrm{J}$.

${ }^{7}$ The actual inflation rate is denoted $\Delta \mathrm{p}_{\mathrm{kt}}$ and defined as $\ln \left[\mathrm{P}_{\mathrm{kl}+1}\right.$ 
parity. ${ }^{8}$ Differentials between nominal interest returns may arise either because of risk premia $\left(\rho_{k t}\right)$ or exchange rate forecast errors $\left(\epsilon_{\mathrm{kt}}\right)$ :

$$
i_{k t}-i_{A t}-\Delta s_{k t}=\rho_{k t}-\epsilon_{k t}
$$

Risk premia arise if investors require an expected excess return on one currency or the other to compensate for the risk of holding that currency. Unlike equity risk premia, there is no presumption that the risk premia should be positive or negative, and indeed exchange risk premia might vary in sign over time. ${ }^{9}$ Forecast errors in the exchange market, defined as $\epsilon_{\mathrm{kt}}=\Delta \mathrm{s}_{\mathbf{k t}}-\Delta \mathrm{x}_{\mathbf{k t}}$, should be random if the market is efficient. But there are several reasons why these errors might be systematic over time. First, investors may anticipate changes in the underlying process generating returns which have yet to occur in the sample period; the classic example of this phenomena is the anticipated devaluation of the Mexican peso in the mid-1970s (hence the term "peso phenomena" by which such phenomena are known). ${ }^{10}$ Second, after there has been a change in regime, investors may learn only gradually the true process governing returns. During

${ }^{8}$ Hodrick (1987) surveys the empirical evidence on uncovered interest parity.

${ }^{9}$ For models of international asset pricing and foreign exchange risk, see Adler and Dumas (1983), Dumas (1994), and Lewis (1994).

${ }^{10}$ For a concise discussion of the peso phenomena, see Froot and Thaler (1990). Rogoff (1979) was among the first to discuss this phenomena. 
the learning process, forecast errors will not be random. ${ }^{11}$

In a similar way, deviations from PPP can be attributed to expected deviations from PPP, $\theta_{\mathbf{k}}$, or to forecast errors in predicting either inflation differentials or exchange rate changes:

$$
\Delta \mathrm{p}_{\mathrm{kt}}-\Delta \mathrm{p}_{\mathrm{At}}-\Delta \mathrm{s}_{\mathrm{kt}}=\theta_{\mathrm{kt}}+\mu_{\mathrm{kt}}-\epsilon_{\mathrm{kt}}
$$

Roll (1978) argues that commodity speculators will keep expected deviations from PPP, $\theta_{\mathrm{k}}$, equal to zero. ${ }^{12}$ This expectations theory of PPP implies that actual deviations from PPP as in (8) are random as long as the errors in forecasting inflation, $\mu_{\mathrm{k}}$, and exchange rates, $\epsilon_{\mathbf{k}}$, are themselves random. Although there is overwhelming evidence against conventional forms of PPP in which no deviations from PPP are supposed to occur, many studies such as Roll (1978) and Adler and Lehman (1983) are unable to reject the hypothesis that deviations from PPP are random. More recent studies by Abuaf and Jorion (1990), Glen (1992), and Lothian and Taylor (1992) are able to find evidence of mean-reversion in deviations from PPP, but only by using much longer spans of price data. The same problems of interpretation confront tests of PPP as tests of UIP. If there are systematic deviations from PPP, they could be caused

${ }^{11}$ Lewis (1989) develops a model in which market participants update their expectations using Bayesian methods.

${ }^{12}$ Speculation in commodities like copper and wheat is easier to imagine than in many of the goods and services that comprise the consumer price index, but Roll intends his theory to apply to all prices in an economy. 
either by ex ante departures from PPP or systematic forecast errors.

Given equations (7) and (8), real interest differentials can be decomposed as follows:

$$
r_{\mathrm{kt}}-\mathrm{r}_{\mathrm{Al}}=\rho_{\mathrm{kt}}-\theta_{\mathrm{kt}}-\mu_{\mathrm{kt}}
$$

According to this expression, real interest differentials arise because of risk premia in the foreign exchange market, expected deviations from PPP, or forecast errors in predicting inflation. The first two factors are associated with ex ante deviations from real interest parity, while inflation forecast errors lead to ex post deviations, whether systematic or not.

Equation (9) shows that exchange rate forecast errors have no effect on the real interest differential. As Mishkin (1984) and others have emphasized, this explains why real interest differentials are so much less volatile than nominal interest differentials or deviations from PPP. Figure 1 illustrates this point by comparing uncovered (nominal) interest differentials with real interest differentials for the mark relative to the dollar. The nominal interest rate series is several times more volatile than the real interest rate series.

The series illustrated represent ex post rather than ex ante deviations from the parity conditions. These ex post deviations could be due solely to random forecast errors. To determine whether there are systematic deviations from real interest parity or the underlying parity conditions, it is necessary to examine conditional estimates of the three parity conditions. As Mishkin (1984) and 
other studies have done, I present conditional tests of the real interest parity conditions obtained by regressing real interest differentials on variables in the current information set, $Z_{k \mathbf{l}}{ }^{13} I$ combine tests of real interest parity with simultaneous tests of the two underlying parity conditions using the same set of information variables. Consider the three equation system relating each differential to the same set of information variables, $Z_{k t}$.

$$
\begin{aligned}
& i_{\mathrm{k} t}-\mathrm{i}_{\mathrm{Al}}-\Delta \mathrm{s}_{\mathrm{kt}}=\gamma_{\mathrm{k} 0}+\gamma_{\mathrm{k}} \mathrm{Z}_{\mathrm{kt}}+\mathrm{u}_{\mathrm{k} t}^{\prime} \\
& \Delta \mathrm{p}_{\mathrm{k} t}-\Delta \mathrm{p}_{\mathrm{Al}}-\Delta \mathrm{s}_{\mathrm{kt}}=\lambda_{\mathrm{k} 0}+\lambda_{\mathrm{k}} \mathrm{Z}_{\mathrm{kt}}+\mathrm{u}_{\mathrm{kt}}^{\prime \prime} \\
& \mathrm{r}_{\mathrm{k} t}-\mathrm{r}_{\mathrm{Al}}=\phi_{\mathrm{k} 0}+\phi_{\mathrm{k}} \mathrm{Z}_{\mathrm{kl}}+\mathrm{u}_{\mathrm{kl}} .
\end{aligned}
$$

If these parity conditions hold, the coefficients of the current information variables should be insignificantly different from zero. If the respective coefficients of the information variables $\left(\gamma_{k}, \lambda_{k}\right.$, and $\left.\phi_{\mathbf{k}}\right)$ are significantly different from zero, the fitted values from these regressions represent the systematic component of any departures from the three parity conditions.

Because deviations from these three parity conditions are driven by common factors such as risk premia and forecast errors as in equations (7)-(9), these equations should be estimated jointly. The three equations are linked by an identity, so only two of the

13 Other tests of real interest parity of a similar form include Mark (1985), Kester and Luehrman (1989), and Dutton (1993). 
three equations can be estimated jointly at any time. If estimated jointly, it is possible to test cross equation restrictions and interpret them in terms of these common factors. Consider two alternative cases:

Case 1: $\quad \gamma_{\mathbf{k}} \neq 0, \Phi_{\mathbf{k}} \neq 0$, but $\lambda_{\mathbf{k}}=0$. That is, there are systematic departures from uncovered interest parity and real interest parity, but not from purchasing power parity. In this case, the evidence of systematic departures from UIP and RIP is consistent with there being a foreign exchange risk premium, $\boldsymbol{\rho}_{\mathrm{kt}}$, causing departures from both parity conditions. It is possible to test for a common factor affecting equations (10a) and (10c) by testing the cross equation restriction, $\gamma_{k}=\phi_{k}$. Since the dependent variable in (10b) is linearly related to those in (10a) and (10c), however, this restriction is equivalent to the test of $\lambda_{k}=0$ in equation (10b).

Case 2. $\gamma_{\mathrm{k}} \neq 0, \lambda_{\mathrm{k}} \neq 0$, but $\phi_{\mathrm{k}}=0$. In this case, the evidence of systematic departures from UIP and PPP is consistent with an exchange market forecast error, $\epsilon_{\mathbf{k}}$, causing (systematic) departures from both parity conditions. The common factor in equations (10a) and (10b) can be tested by the cross equation restrictions, $\gamma_{k}=\lambda_{k}$. But this restriction is equivalent to the test of $\phi_{k}=0$ in equation (10c).

Thus jointly testing the three parity conditions offers the possibility of distinguishing between the two alternative reasons for deviations from uncovered interest parity, risk premia and foreign systematic exchange forecast errors. To test these restrictions, I use a Wald test 
with the test statistic distributed as $\chi^{2}(\mathrm{~N})$, where $N$ is the number of information variables in an equation (excluding the constant).

If instead of these cases, there is evidence of systematic departures from all three parity conditions, then this is consistent with the coexistence of both foreign exchange risk premia and systematic forecast errors in the foreign exchange market. ${ }^{14}$ In that case, deviations between any two of the parity conditions may move independently of one another as inspection of equations (7)-(9) makes clear. ${ }^{15}$

There is an interesting alternative hypothesis that can be tested -- that these deviations are perfectly correlated with one another (even if they are not equal in size). This perfect correlation occurs if a common nominal disturbance affects both inflation forecast errors $\left(\mu_{\mathrm{kt}}\right)$ and foreign exchange forecast errors $\left(\epsilon_{\mathrm{kt}}\right)$ so that $\boldsymbol{\mu}_{\mathrm{kt}}=\mathrm{h}_{1} \epsilon_{\mathrm{kt}}$, where $\mathrm{h}_{1}$ is a constant. ${ }^{16}$ One example of such a common disturbance is a shift in the monetary regime such as

${ }^{14}$ It should be noted, however, that the same pattern is also consistent with there being no systematic forecast errors, since ex ante deviations from PPP $\left(\theta_{k t}\right)$ together with risk premia $\left(\boldsymbol{\rho}_{\mathrm{kt}}\right)$ are sufficient to account for deviations from all three parity conditions.

${ }^{15}$ The three equations are still tied together, so only two can be independent.

${ }^{16}$ Perfect correlation could also occur if risk premia were perfectly correlated with forecast errors or ex ante PPP deviations, but such correlation is more difficult to justify. 
occurred in the United States in 1979. ${ }^{17}$ If agents are not fully informed about such a shift, they will make forecast errors in predicting both inflation and foreign exchange rates. Because the two forecast errors appear in all three parity conditions, the perfect correlation between these errors will lead to linear relationships among all three parity conditions:

Case 3. $\phi_{k}=h_{1} \gamma_{k}$, and $\lambda_{k}=\left(1-h_{1}\right) \gamma_{k}$ where $h_{1}$ is the same proportionality factor tying the forecast errors together. ${ }^{18}$ For the deviations from all three parity conditions to be positively correlated, the proportionality factor, $h_{1}$, must be between zero and one. ${ }^{19}$

To test this hypothesis of proportionality between the coefficients, I can use a J-statistic developed by Hansen (1982) to test proportionality restrictions. ${ }^{20}$ This statistic is asymptotically distributed as $\chi^{2}$ with degrees of freedom equal to $N-1$ where $N$ is the number of information variables in the equation.

${ }^{17}$ Another example would be a shift in exchange rate regime between fixed and flexible rates or between different sets of exchange rate targets.

${ }^{18}$ Because of the cross equation restrictions, $\lambda_{k}=\left(\gamma_{k}-\phi_{k}\right)$.

${ }^{19}$ If $h_{1}=1$, for example, then the nominal disturbance has no effect on the PPP deviation (i.e., $\lambda_{\mathbf{k}}=0$ ).

${ }^{20}$ Cumby and Huizinga (1992) recently used this statistic to test for proportionality between exchange rate changes and inflation differentials as well as between other variables. 


\section{Joint Tests of the Parity Conditions for Eurocurrency Rates}

To test the parity conditions, I will first examine one month Eurocurrency interest rates. Eurocurrency interest rates are used in preference to national money market rates for two reasons. ${ }^{21}$ First, during much of the period of study, the British, French, and Japanese governments maintained controls inhibiting capital flows between the national market and markets abroad. ${ }^{22}$ Second, the national money markets, particularly in Japan and France, were restricted by national regulations and conventions; prior to 1979, for example, no CD market existed in Japan, while French CD rates were subject to ceilings for several years during the 1980s.

To form real interest rates as well as the PPP deviations, two price series are used: the consumer price index (CPI) and the producer price index in manufacturing (PPIM). The CPI contains a broad set of traded and non-traded goods and services, while the PPIM is confined to manufactured products which are largely traded. So the real interest rate defined in terms of the PPIM is more representative of real financing costs faced by internationallyoriented firms. The real interest rate defined in terms of the CPI, in contrast, is more representative of real returns faced by investors as well as the real financing costs faced by domestically-oriented

21 The Eurocurrency interest rates are end-of-month rates from Data Resources Inc. They begin in June 1973, a few months after the major currencies began generalized floating.

${ }^{22}$ Germany and the United States removed most of their controls in 1973. 
firms. Estimates of real interest differentials as well as PPP differentials are reported for both sets of price indexes. The French government stopped publishing producer price indexes in 1985, so the French equations reported are for the consumer price index alone.

Table 1 reports conditional tests of all three parity conditions. Equations are estimated for the four dollar exchange rates of the G-5 countries using a heteroskedasticity-consistent estimator. ${ }^{23}$ The choice of information variables to include in $Z_{\mathrm{kt}}$ is inevitably somewhat arbitrary; any variable in the current information set is a potential candidate. The variables chosen include two sets of financial variables: the simple interest differentials $\left(i_{\mathrm{kl}}-\mathrm{i}_{\mathrm{Al}}\right)$ between the Eurocurrency markets for currency $k$ and the dollar and the share yield in the two countries, the latter being a variable often used in studies of risk premia in equity markets. ${ }^{24}$ The variables also include an inflation variable, the inflation differential between the two countries over the past twelve months, because the same information variables will be used in the PPP equation as in the nominal and real interest parity equations. Thus there are four information variables in all: the interest differential, share yields in the two countries, and the inflation differential between these two

${ }^{23}$ Since Eurocurrency interest rates are of one month maturity, there are no overlapping observations which would lead to serially correlated disturbances.

${ }^{24}$ Risk premia in equity and foreign exchange markets should be driven by common factors, a point emphasized by Bekaert and Hodrick (1992) who show that share yields have explanatory power in both sets of markets. 
countries.

The Wald tests reported in Table 1 are to determine if the coefficients of the information variables (all except the constant) in an equation are equal to zero. As explained above, each test is equivalent to a test for the equality of the coefficients in the other two equations because the three dependent variables are linearly related. Thus, for example, the test of whether the coefficients in the PPP equation are equal to zero, $\lambda_{k}=0$, is equivalent to the test of whether the coefficients in the UIP equation are equal to the coefficients in the RIP equation, $\gamma_{k}=\phi_{k}$. The test statistic is distributed as $\chi^{2}$ with four degrees of freedom. The J-statistic tests whether the fitted values of the UIP and PPP equations are proportional to each other even if they are not equal. As explained above, this test is the same as testing proportionality between fitted values of the UIP and RIP equations, since the three equations are linearly related. The figure in square brackets below each $\chi^{2}$-statistic is the p-value for the null hypothesis.

Consider first the equations estimated with consumer price indexes. The results of the estimation for the $\$ / £$ and $D M / \$$ rates are quite definitive. All three parity conditions are rejected at one percent levels of significance. And the hypothesis of perfect correlation between the UIP and PPP deviations is also rejected at about the one percent level. So there is evidence that deviations from all three parity conditions are systematically related to variables currently known to market participants. Yet these deviations are not perfectly correlated, so there is no reason to believe that one 
common disturbance is causing these deviations. This evidence is consistent with the coexistence of both risk premia and systematic forecast errors. Estimates based on producer prices in manufacturing are consistent with the same interpretation.

The results for the $\mathrm{FF} / \$$ rate are more complicated. There is strong evidence that deviations from UIP and RIP are systematically related to current variables. But the p-value for $\lambda_{k}=$ 0 is 0.130 , so deviations from PPP are not statistically different from zero at the ten percent level. The same statistic also applies to the equality of coefficients in the equations for UIP and RIP deviations $\left(\gamma_{k}=\phi_{k}\right)$; it is not possible to reject the hypothesis that these coefficients are identical. Evidence from the three Wald tests is thus consistent with there being a risk premium driving deviations from UIP and RIP but no systematic forecast error. The risk premium causes deviations from UIP and RIP, but not PPP.

This interpretation of the Wald tests for France, however, is not consistent with the J-statistic for the hypothesis of perfect correlation. With a p-value of 0.427 for this statistic, it is not possible to reject the hypothesis that deviations from UIP and PPP for France are perfectly correlated. As explained above, perfect correlation can occur when there is a common factor driving exchange market and inflation forecast errors in all three equations. So perhaps deviations from PPP are systenuatically related to current variables after all -- driven by the same forecast errors which cause deviations from UIP and RIP.

The $¥ / \$$ equations yield results which are quite different 
from those of the other equations. In the equations based on consumer prices, neither UIP nor PPP can be rejected at conventional levels of significance, although RIP can be rejected. In the equations based on producer prices in manufacturing in the bottom half of Table 1, even real interest parity cannot be rejected. If all three parity conditions hold, this is consistent with forecast errors being random (i.e., non-systematic) and risk premia being unimportant. $^{25}$ The J-statistic cannot reject proportionality between coefficients, but this test is more difficult to interpret when the underlying parity conditions cannot be rejected. ${ }^{26}$ So the Japanese evidence stands apart from the other G-5 evidence, although this may simply be due to greater noise in the Japanese series making it more difficult to reject the parity conditions. Unlike in Japan, in all of the other countries there is ample evidence of departures from the three parity conditions.

\section{Joint Tests of the Parity Conditions for Bonds}

If average real interest differentials are generally small between short term instruments then it is natural to ask if the same is true of real interest differentials between bonds. To measure real

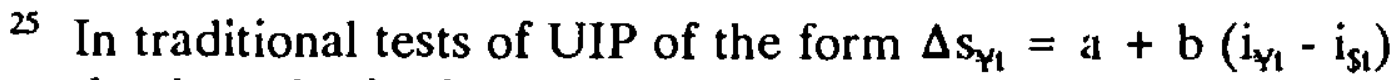
$+v_{v}$, the hypothesis that $a=0$ and $b=1$ cannot be rejected at conventional levels of significance -- a result also consistent with there being random forecast errors and no foreign exchange risk premium.

${ }^{26}$ In the extreme case when $\lambda_{k}=\gamma_{k}=0$, then proportionality between these coefficients is of no interest at all. 
bond returns for investors, it is preferable to use the returns on government rather than corporate bonds because in most countries the government bond market is much larger and more liquid than the corporate market. For that reason, internationally diversified portfolios are said to hold much larger proportions of government bonds than corporate bonds. To measure the real cost of financing for firms, however, it would be preferable to use corporate bond yields. But government bond data are more readily available and are of higher quality than corporate bond data. ${ }^{27}$

The real interest rate for a medium or long term bond is more difficult to define than for a short term instrument. If the bond has a maturity of $\mathrm{n}$ periods, one definition of the real interest rate would be the expected real return over $n$ periods. The nominal return can be measured by the yield to maturity of the $n$ period bond, $\mathrm{n}_{\mathrm{n}} \cdot{ }^{28}$ So the real return can be obtained by deflating by some measure of expected inflation, ${ }_{n} \pi_{1}$ :

$$
E_{l}\left({ }_{n} r_{1}^{\prime}\right)={ }_{n} i_{1}-{ }_{n} \pi_{1}
$$

This is the definition of the real interest rate found in the literature

${ }^{27}$ Returns on Eurobonds would be interesting to compare, but there are no consistently defined yield series extending back into the 1970 s.

${ }^{28}$ To simplify the notation, the subscript $k$ for country $k$ is omitted from the expressions in this section. 
comparing the cost of capital internationally. ${ }^{29}$ Since what is being measured is the cost of financing or the return to investing over $n$ periods, the expected inflation rate should match the horizon of ${ }_{n} i_{t}$. That is, ${ }_{n} \pi_{t}$ should be interpreted as the inflation rate expected over the life of the bond. Unless the bond is a pure discount bond, moreover, the inflation rate has to be defined so as to match the intermediate as well as terminal cash flows on the bond. As a result, this version of the real interest rate is difficult to implement empirically. ${ }^{30}$

An investor evaluating this bond would normally prefer to examine returns over a shorter horizon than the maturity of the bond. In fact, the investor may be interested in returns over a holding period corresponding to the maturity of short term assets like Eurocurrencies. The nominal return over such a period is given by the holding period yield, ${ }_{n} \mathrm{H}_{4}$, defined as the capital gain plus coupon payment received on the bond between $t$ and $t+1$ :

$$
{ }_{11} \mathrm{H}_{t}=\left(B_{t+1} / B_{t}-1\right)+C / B_{v}
$$

${ }^{29}$ Most of these studies calculate a weighted average of the real rate on bank loans and the real rate on bonds where the latter is defined as in (11). McCauley and Zimmer (1989) survey this literature.

${ }^{30}$ An alternative interpretation of (11) is that ${ }_{\mathrm{n}^{\prime}}{ }^{\prime}$ is being measured over a shorter interval than the maturity of the bond, but then some strong assumptions have to be made about the relationship between the yield to maturity of the bond and expected yields over shorter intervals. 
where $B_{t}$ is the price of the bond and $C$ is the coupon. Thus an alternative expression for the real interest rate is formed by deflating the holding period yield (in logs) by the same one-period expected inflation rate used to deflate Eurocurrency deposits: ${ }^{31}$

$$
E_{t}\left({ }_{n} r_{t}\right)=E_{t}\left({ }_{n} h_{t}\right)-\pi_{t},
$$

where ${ }_{n} h_{t}=\ln \left(1+{ }_{n} H_{t}\right)$. This second measure of the real interest rate is linked to the first measure, since the price paid for the bond (and hence the yield to maturity) is related to expected holding period returns. But this second measure is more precisely defined and therefore easier to measure in practice. The one drawback of this measure is that it is more appropriate for an investor than for a borrower, since the latter is more likely to be interested in real financing costs over the life of the bond.

Morgan Guaranty Trust recently developed a series for holding period yields on government bonds based directly on bond market prices. This series, which is based on prices for a broad range of intermediate-term government bonds accessible to international investors, extends back to December $1985 .{ }^{32}$ For the period prior to 1985 , I have constructed a holding period series from

${ }^{31}$ This is the measure used by Huizinga and Mishkin (1984) who examine real returns on a variety of longer term U.S. bonds.

${ }^{32}$ The bonds are described in Morgan Guaranty Trust (1989). They are generally shorter in maturity than the earlier yield to maturity series published by Morgan with the biggest differences occurring in the case of U.S. and British bonds. 
yield to maturity data using a linear approximation due to Shiller (1979). The yield to maturity data, from Morgan's World Financial Markets, extend back to the early 1970s, but I begin the sample in June 1973, the same month as the Eurocurrency data. The linear approximation is for an n-period bond with yield to maturity (in levels) of ${ }_{n^{*}}{ }^{*}$ and duration ${ }_{n} D^{33}$ The duration of a bond is a coupon-adjusted time to maturity (to reflect the fact that coupons shorten the effective maturity of the bond). If $\mathrm{c}$ is the coupon rate (expressed as a fraction of the principal), then the duration of this bond is given by:

$$
{ }_{n} D=\frac{\left[g c+2 g^{2} c+\ldots+n g^{n} c+n g^{n}\right]}{\left[g c+g^{2} c+\ldots+g^{n} c+g^{n}\right]}
$$

where $\mathrm{g}=1 /\left[1+{ }_{\mathrm{n}^{*}}{ }^{*}\right]$. For a bond selling at par, the coupon rate is equal to ${ }_{n}{ }^{*}$. In that case, the duration is given by ${ }_{n} D=(1-$ $\left.\mathrm{g}^{\mathrm{n}}\right) /(1-\mathrm{g})$. The holding period yield from $\mathrm{t}$ to $\mathrm{t}+1,{ }_{\mathrm{a}} \mathrm{H}_{\mathrm{t}}$, can then be expressed as a function of current yields to maturity, ${ }_{n} I_{t}$, by linearizing (12) around ${ }_{n} I^{*}$ to obtain:

$$
{ }_{n} H_{t} \cong\left({ }_{n} D\right){ }_{n} I_{t}-\left({ }_{n} D-1\right)_{n-1} I_{t+1} .
$$

So the holding period yield in period $t$ is related to the yield to maturity of an $n$ period bond at time $t$ relative to the yield to maturity of an $n-1$ period bond at $t+1$. Figure 2 compares the

${ }^{33}$ This particular formulation using durations is from Shiller, Campbell, and Schoenholtz (1983). 
derived series for U.S. bonds with the corresponding Morgan series based directly on bond price data. Over the period when both series are available, December 1985 to February 1992, the correlation coefficient between the derived and Morgan series is $0.96 .{ }^{34}$ The combined holding period series extends from June 1973 to December 1992.

The holding period yields will be used to conduct tests of the same form as the Eurocurrency tests. Thus the tests will examine whether nominal and real differentials are systematically related to variables in the current information set. In these tests actual holding period yields will differ from expected holding period yields because of forecast errors. So the nominal and real yield differentials between currency $k$ and the dollar will be subject to an additional factor not found in the Eurocurrency differentials. Equations (7) and (9) now become

$$
\begin{aligned}
& { }_{\mathrm{n}} \mathrm{h}_{\mathrm{kt}}-{ }_{\mathrm{n}} \mathrm{h}_{\mathrm{At}}-\Delta s_{\mathrm{kt}}=\rho_{\mathrm{kt}}+v_{\mathrm{kt}}-\epsilon_{\mathrm{kt}} . \\
& { }_{\mathrm{n}} \mathrm{r}_{\mathrm{kt}}-{ }_{\mathrm{n}} \mathrm{r}_{\mathrm{Al}}=\rho_{\mathrm{kt}}-\theta_{\mathrm{kt}}+v_{\mathrm{kt}}-\mu_{\mathrm{kt}} .
\end{aligned}
$$

where $v_{k t}=\left({ }_{n} h_{k t}-{ }_{n} h_{A t}\right)-\left(E_{1 n} h_{k t}-E_{1 n} h_{A t}\right)$ is the forecast error in predicting nominal holding period yields. (The inflation differential or deviation from PPP given by (8) is unaffected). This additional forecast error complicates the interpretation of the three

${ }^{34}$ The correlation between the corresponding series for Britain is 0.92 , for France 0.89 , for Germany 0.93 , and for Japan 0.88 . 
differentials. If there are nominal and real yield differentials but no PPP differentials, these could be due to forecast errors in predicting holding period yields instead of or in addition to foreign exchange risk premia.

Table 2 reports the results of estimating equations relating nominal yield differentials, PPP deviations, and real yield differentials to variables in the current information set. This information set includes the four variables used in the Eurocurrency equations. In addition to the one-month Eurocurrency differential, however, I also include the differential between the yields to maturity of the bonds, ${ }_{n} i_{k t}-{ }_{n} i_{A v}$. So there are five variables in the information set in each equation. As in the case of Table 1, this table reports the Wald tests to determine if the nominal and real yield differentials and the PPP differentials are systematically related to the information variables and $\mathrm{J}$-statistics to test for proportionality between the coefficients in the equations for the nominal yield differentials and PPP deviations.

The results of the estimation for the $\mathrm{FF} / \$$ and $\mathrm{DM} / \$$ rates are sufficiently similar so that they can be considered together. In both cases, all three differentials are significantly different from zero at the five percent level. That is, the nominal yield differential, the PPP differential, and the real yield differential are all systematically related to currently known variables. This pattern is consistent with the coexistence of both risk premia and systematic forecast errors. The one difference between the two exchange rates lies in the J-test. In the case of the FF/ $\$$ rate, it is not possible to reject the 
hypothesis that the yield differentials and PPP differentials are perfectly correlated. The J-statistic testing that hypothesis has a pvalue of 0.586. So as in the case of the French franc/dollar Eurocurrency differential, it is not possible to rule out the possibility that the differentials in all three equations are driven by a common nominal disturbance.

In the case of the $\$ / £$ rate, both nominal yield differentials and PPP differentials are systematically related to currently known variables. But this is not true of real yield differentials. It is not possible to reject the hypothesis that real yields on sterling and dollar bonds are the same $\left(\phi_{\mathbf{k}}=0\right)$ or, equivalently, that nominal yields move together with PPP deviations $\left(\gamma_{k}=\lambda_{k}\right)$. So systematic foreign exchange forecast errors rather than risk premia appear important in this case. In the case of the $¥ / \$$ rate, the opposite is true. There is evidence that both nominal and real interest differentials are systematically related to current variables, but not PPP differentials. So this evidence suggests that risk premia (or forecast errors in predicting holding period yields) are important rather than foreign exchange forecast errors.

In the case of both exchange rates, however, the J-statistics have high p-values, so it is not possible to reject the hypothesis that (the systematic components of ) nominal yield differentials and PPP differentials are perfectly correlated. Since correlation between any two differentials implies correlation with the third differential, there may be a common factor driving differentials in all three equations. Under this interpretation, nominal disturbances may be causing 
simultaneous forecast errors in predicting foreign exchange rates and inflation rates (and perhaps holding period yields as well). These errors must be systematic, however, since it is the fitted values (or systematic components) of these forecast errors which are correlated.

It should be pointed out that the results for bond yields are quite similar to those for Eurocurrency differentials. In both Tables 1 and 2, most of the Wald tests result in rejections of the coefficient restrictions. Thus there is evidence that most nominal differentials between Eurocurrency rates and between bond yields are systematically related to currently known variables. And the same can be said for real differentials and PPP deviations.

\section{E. Concluding Remarks}

This study has provided ample evidence that interest differentials between countries cannot be attributed to either risk premia or systematic forecast errors alone. Evidence from both Eurocurrency markets and bond markets suggest strongly that in most cases both factors are at work in separating markets.

The study has shown that if risk premia alone are important, then there are cross equation restrictions between nominal and real interest differentials, or, equivalently, systematic deviations from UIP and RIP but not PPP. If systematic forecast errors are important instead, there are cross equation restrictions between nominal interest differentials and PPP deviations. If both factors are important, however, then these cross equation restrictions will be rejected. The evidence suggests that most of these cross equations restrictions can be rejected. Or, equivalently stated, the deviations 
from each of these three parity equations are, in most cases, systematically related to variables in the current information set. Perhaps the most intriguing evidence is that for some currencies, these three sets of deviations are perfectly correlated, suggesting that a common factor may be driving all three deviations.

The challenge facing researchers is to formulate empirically testable asset pricing models to explain risk premia or models of peso phenomena or learning behavior to explain systematic forecast errors. Such efforts would provide more direct evidence that one or more factors are important in explaining deviations from the three parity conditions. Such efforts to date have met with only limited success. 


\section{REFERENCES}

Abuaf, Niso, and Philippe Jorion, 1990. "Purchasing Power Parity in the Long Run," Journal of Finance, March, 157-174.

Adler, Michael, and Bernard Dumas, 1983. "International Portfolio Choice and Corporation Finance: A Synthesis." Journal of Finance, June, 925-984.

Adler, Michael; and Bruce Lehmann, 1983. "Deviations from Purchasing Power Parity in the Long Run," Journal of Finance, December, pp. 1471-87.

Bekaert, Geert, and Robert J. Hodrick, 1992. "Characterizing Predictable Components in Excess Returns on Equity and Foreign Exchange Markets," Journal of Finance, June, 467-509.

Cumby, Robert E., and John Huizinga, 1992. "Investigating the Correlation of Unobserved Expectations: Expected Returns in Equity and Foreign Exchange Markets and Other Examples," Journal of Monetary Economics, November, 217-253.

Cumby, Robert E., and Maurice Obstfeld, 1984. "International Interest Rate and Price Level Linkages under Flexible Exchange Rates: A Review of Recent Evidence," Exchange Rate Theory and Practice, John Bilson and Richard Marston, editors, pp. 121-51. Chicago: University of Chicago Press.

Dumas, Bernard, 1994. "Partial-Equilibrium vs. GeneralEquilibrium Models of International Capital Market Equilibrium," Handbook of International Macroeconomics, Frederick van der Ploeg, editor. Oxford: Blackwell.

Dutton, Marilyn Miller, 1993. "Real Interest Parity: New Measures and Tests," Journal of International Money and Finance, February, 62-77.

Frankel, Jeffrey A., 1986. "International Capital Mobility and Crowding-Out in the U.S. Economy: Imperfect Integration of Financial Markets or of Goods Markets?" How Open is the U.S. 
Economy?, R.W. Hafer, editor. Lexington, Mass.: Lexington Books.

Froot, Kenneth A., and Richard H. Thaler, 1990. "Anomalies: Foreign Exchange," Journal of Economic Perspectives, Summer, 179-192.

Glen, Jack D., 1992. "Real Exchange Rates in the Short, Medium, and Long Run," Journal of International Economics, August, 147 . 166.

Hansen, Lars P., 1982. "The Large Sample Properties of Generalized Method of Moments Estimators," Econometrica, 1029-1054.

Hodrick, Robert, 1987. The Empirical Evidence on the Efficiency of Forward and Futures Foreign Exchange Markets. Chur:

Harwood Academic Publishers.

Huizinga, John, and Frederic S. Mishkin, 1984. "Inflation and Real Interest Rates on Assets with Different Risk Characteristics," Journal of Finance, July, 699-712.

Kester and Luehrmann, 1989. "Real Interest Rates and the Cost of Capital: A Comparison of the United States and Japan," Japan and the World Economy, July, 279-301.

Lewis, Karen K., 1989. "Changing Beliefs and Systematic Rational Forecast Errors with Evidence from Foreign Exchange," American Economic Review, September, 621-36.

Lewis, Karen K., 1994. "Puzzles in International Financial Markets," Handbook of International Economics, G. Grossman and K. Rogoff, editors, Amersterdam: North-Holland.

Lothian, James R., and Mark P. Taylor, 1992. "Real Exchange Rate Behavior: The Recent Float from the Perspective of the Past Two Centuries," November, processed. 
Mark, Nelson C., 1985. "Some Evidence on the International Equality of Real Interest Rates," Journal of International Money and Finance, June, 189-208.

McCauley, Robert N., and Steven A. Zimmer, 1989. "Explaining International Differences in the Cost of Capital," Quarterly Review, Federal Reserve Bank of New York, Summer, 7-28.

Mishkin, Frederic S., 1984. "Are Real Interest Rates Equal Across Countries? An Emirical Investigation of International Parity Conditions," Journal of Finance, December, 1345-1357.

Morgan Guaranty Trust, 1989. "The J.P. Morgan Government Bond Index," World Financial Markets, November 22, 5-13.

Rogoff, Kenneth (1979). "Essays on Expectations and Exchange Rate Volatility." Ph.D. Dissertation, Massachusetts Institute of Technology.

Roll, Richard, 1979. "Violations of Purchasing Power Parity and Their Implications for Efficient International Commodity Markets," International Finance and Trade, Marshall Sarnat and G.P. Szego, editors, pp. 133-76 Cambridge, Mass.: Ballinger Publishing Co.

Shiller, Robert J., 1979. "The Volatility of Long-Term Interest Rates and Expectations Models of the Term Structure," Journal of Political Economy, December, 1190-1219.

Shiller, Robert J., John Y. Campbell, and Kermit L. Schoenholtz, 1983. "Forward Rates and Future Policy: Interpreting the Term Structure of Interest Rates," Brookings Papers on Economic Activity, No.1, 173-217. 


\begin{tabular}{|c|c|c|c|c|}
\hline \multicolumn{5}{|c|}{$\begin{array}{l}\text { TESTS FOR PREDICTABLE COMPONENTS IN UIP, PPP, AND RIP DEVLATIONS } \\
\text { FOR ONE MONTH EUROCURRENCY RATES, 1973(6)-1992(12) }\end{array}$} \\
\hline & $\gamma_{k}=0$ & $\begin{array}{c}\lambda_{k}=0 \\
\left(\phi_{k}=\gamma_{k}\right)\end{array}$ & $\begin{array}{c}\phi_{k}=0 \\
\left(\lambda_{k}=\gamma_{k}\right)\end{array}$ & $\begin{array}{c}\text { J-statistic } \\
\left(\lambda_{k}=h_{1} \gamma_{k}\right)\end{array}$ \\
\hline \multicolumn{5}{|c|}{ CPI Escimates } \\
\hline$\$ / 1$ & $\begin{array}{l}28.56 \\
{[.000]}\end{array}$ & $\begin{array}{l}22.91 \\
{[.000]}\end{array}$ & $\begin{array}{l}28.41 \\
{[.000]}\end{array}$ & $\begin{array}{l}12.23 \\
{[.007]}\end{array}$ \\
\hline $\mathrm{FF} / \$$ & $\begin{array}{l}12.19 \\
{[.016]}\end{array}$ & $\begin{array}{c}7.12 \\
{[.130]}\end{array}$ & $\begin{array}{l}131.03 \\
{[.000]}\end{array}$ & $\begin{array}{r}2.78 \\
{[.427]}\end{array}$ \\
\hline $\mathrm{DM} / \mathrm{s}$ & $\begin{array}{l}21.02 \\
{[.000]}\end{array}$ & $\begin{array}{l}17.18 \\
{[.002]}\end{array}$ & $\begin{array}{r}76.34 \\
{[.000]}\end{array}$ & $\begin{array}{l}10.93 \\
{[.012]}\end{array}$ \\
\hline$\Psi / \$$ & $\begin{array}{c}4.51 \\
{[.341]}\end{array}$ & $\begin{array}{c}2.98 \\
{[.562]}\end{array}$ & $\begin{array}{l}15.01 \\
{[.005]}\end{array}$ & $\begin{array}{r}1.90 \\
{[.594]}\end{array}$ \\
\hline \multicolumn{5}{|c|}{ PPIM Estimates } \\
\hline$\$ / E$ & $\begin{array}{l}28.05 \\
{[.000]}\end{array}$ & $\begin{array}{l}21.41 \\
{[.000]}\end{array}$ & $\begin{array}{l}28.48 \\
{[.000]}\end{array}$ & $\begin{array}{c}9.99 \\
{[.019]}\end{array}$ \\
\hline $\mathrm{DM} / \$$ & $\begin{array}{l}19.16 \\
{[.000]}\end{array}$ & $\begin{array}{l}14.52 \\
{[.006]}\end{array}$ & $\begin{array}{l}75.19 \\
{[.000]}\end{array}$ & $\begin{array}{l}10.65 \\
{[.014]}\end{array}$ \\
\hline$¥ / \$$ & $\begin{array}{r}3.99 \\
{[.407]}\end{array}$ & $\begin{array}{r}1.75 \\
{[.781]}\end{array}$ & $\begin{array}{c}6.11 \\
{[.191]}\end{array}$ & $\begin{array}{r}1.44 \\
{[.696]}\end{array}$ \\
\hline \multicolumn{5}{|c|}{$\begin{array}{l}\text { Note: the first three columns report } \chi^{2}(4) \text { tests of the coefficient restrictions with the p-value } \\
\text { in square brackets. The last column reports the J-Statistic testing the proportionality of } \\
\text { coefficients in the equations for the UIP and PPP deviations; } i t \text { is distributed as } \chi^{2}(3) \text {. }\end{array}$} \\
\hline
\end{tabular}




\begin{tabular}{|c|c|c|c|c|}
\hline \multicolumn{5}{|c|}{ TABLE 2} \\
\hline \multicolumn{5}{|c|}{ TESTS FOR PREDICTABLE COMPONENTS IN UIP, PPP, AND RIP DEVIATIONS } \\
\hline \multicolumn{5}{|c|}{ FOR HOLDING PERIOD YIELDS ON GOVERNMENT BONDS, 1973(6)-1992(12) } \\
\hline & $\gamma_{k}=0$ & $\begin{array}{c}\lambda_{k}=0 \\
\left(\phi_{k}=\gamma_{k}\right)\end{array}$ & $\begin{array}{c}\phi_{k}=0 \\
\left(\lambda_{k}=\gamma_{k}\right)\end{array}$ & $\begin{array}{c}\text { J-statistic } \\
\left(\lambda_{\mathrm{k}}=h_{1} \gamma_{\mathrm{k}}\right)\end{array}$ \\
\hline \multicolumn{5}{|l|}{ CPI Estimates } \\
\hline$\$ / 1$ & $\begin{array}{l}28.70 \\
{[.000]}\end{array}$ & $\begin{array}{l}26.33 \\
{[.000]}\end{array}$ & $\begin{array}{r}7.68 \\
{[.174]}\end{array}$ & $\begin{array}{r}0.99 \\
{[.912]}\end{array}$ \\
\hline $\mathrm{FF} / \mathrm{S}$ & $\begin{array}{l}23.44 \\
{[.000]}\end{array}$ & $\begin{array}{l}12.66 \\
{[.027]}\end{array}$ & $\begin{array}{l}15.58 \\
{[.008]}\end{array}$ & $\begin{array}{c}2.83 \\
{[.586]}\end{array}$ \\
\hline $\mathrm{DM} / \mathrm{s}$ & $\begin{array}{l}18.36 \\
{[.002]}\end{array}$ & $\begin{array}{l}17.51 \\
{[.004]}\end{array}$ & $\begin{array}{l}18.37 \\
{[.003]}\end{array}$ & $\begin{array}{r}9.30 \\
{[.054]}\end{array}$ \\
\hline$¥ / 5$ & $\begin{array}{c}9.55 \\
{[.089]}\end{array}$ & $\begin{array}{c}4.47 \\
{[.483]}\end{array}$ & $\begin{array}{l}13.91 \\
{[.016]}\end{array}$ & $\begin{array}{r}4.25 \\
{[.374]}\end{array}$ \\
\hline \multicolumn{5}{|l|}{ PPIM Estimates } \\
\hline$\$ / \mathbb{E}$ & $\begin{array}{l}26.54 \\
{[.000]}\end{array}$ & $\begin{array}{l}22.73 \\
{[.000]}\end{array}$ & $\begin{array}{r}8.77 \\
{[.119]}\end{array}$ & $\begin{array}{r}1.76 \\
{[.780]}\end{array}$ \\
\hline $\mathrm{DM} / \mathrm{S}$ & $\begin{array}{l}16.01 \\
{[.007]}\end{array}$ & $\begin{array}{l}15.41 \\
{[.009]}\end{array}$ & $\begin{array}{l}24.11 \\
{[.000]}\end{array}$ & $\begin{array}{l}11.20 \\
{[.024]}\end{array}$ \\
\hline$¥ / \$$ & $\begin{array}{l}10.69 \\
{[.058]}\end{array}$ & $\begin{array}{c}2.78 \\
{[.733]}\end{array}$ & $\begin{array}{l}16.97 \\
{[.005]}\end{array}$ & $\begin{array}{r}2.14 \\
{[.710]}\end{array}$ \\
\hline $\begin{array}{l}\text { Note: the first th } \\
\text { in square bracke } \\
\text { coefficients in th }\end{array}$ & $\begin{array}{l}\text { imns re } \\
\text { last col }\end{array}$ & $\begin{array}{l}\text { ests of } \\
\text { ts the J-S } \\
\text { nd PPP }\end{array}$ & $\begin{array}{l}\text { ent restri } \\
\text { ting the }\end{array}$ & $\begin{array}{l}\text { vith the p-value } \\
\text { ionality of } \\
\text { as } \chi^{2}(4) \text {. }\end{array}$ \\
\hline
\end{tabular}




\section{FIGURE 1 \\ NOMINAL AND REAL INTEREST DIFFERENTIALS}

ONE MONTH EURODOLLAR AND EUROMARK RATES AND CPIS

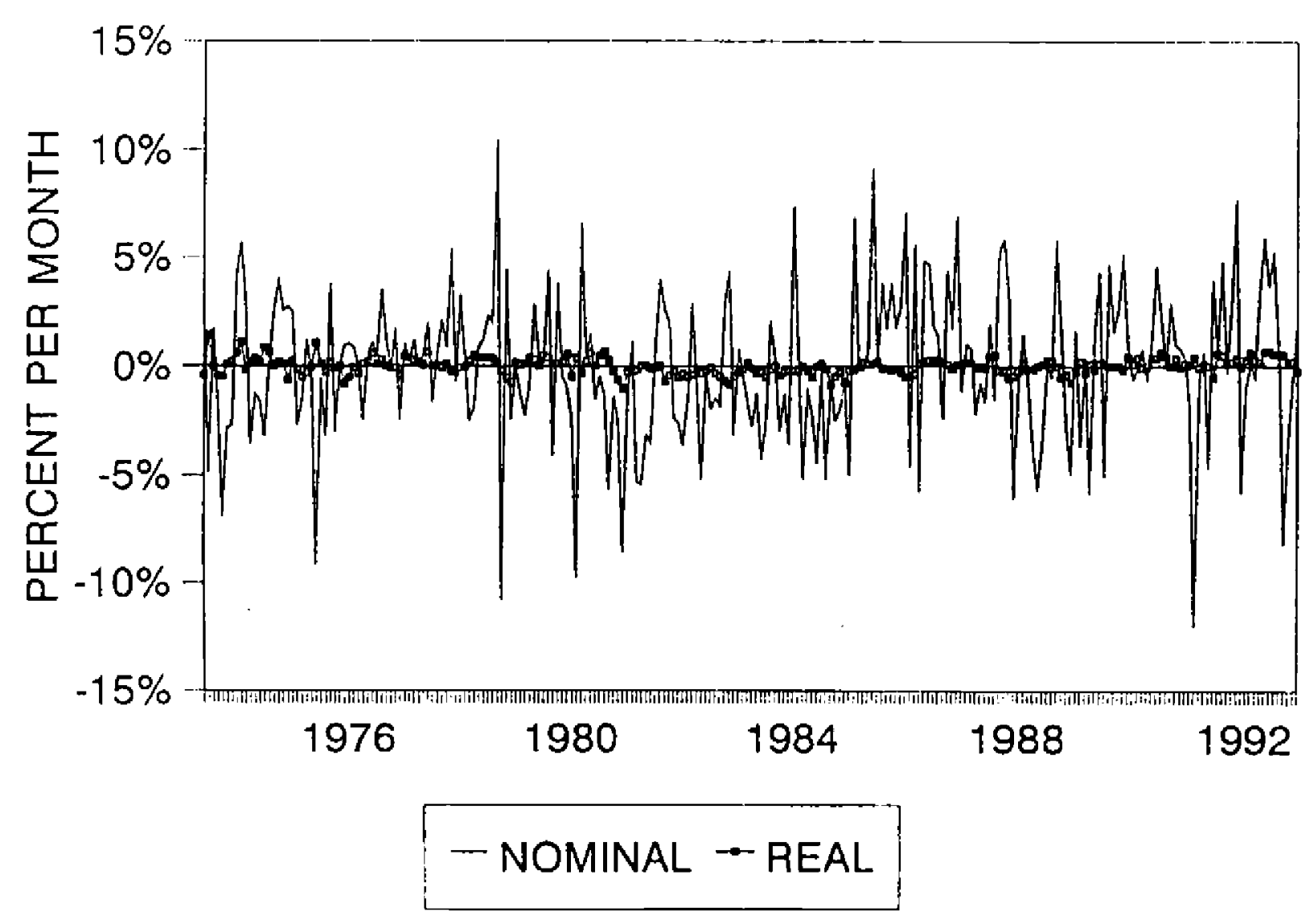


FIGURE 2

COMPARISON BETWEEN DERIVED AND MORGAN HOLDING PERIOD YIELDS FOR U.S. BONDS, 1985(12)-1992(2)

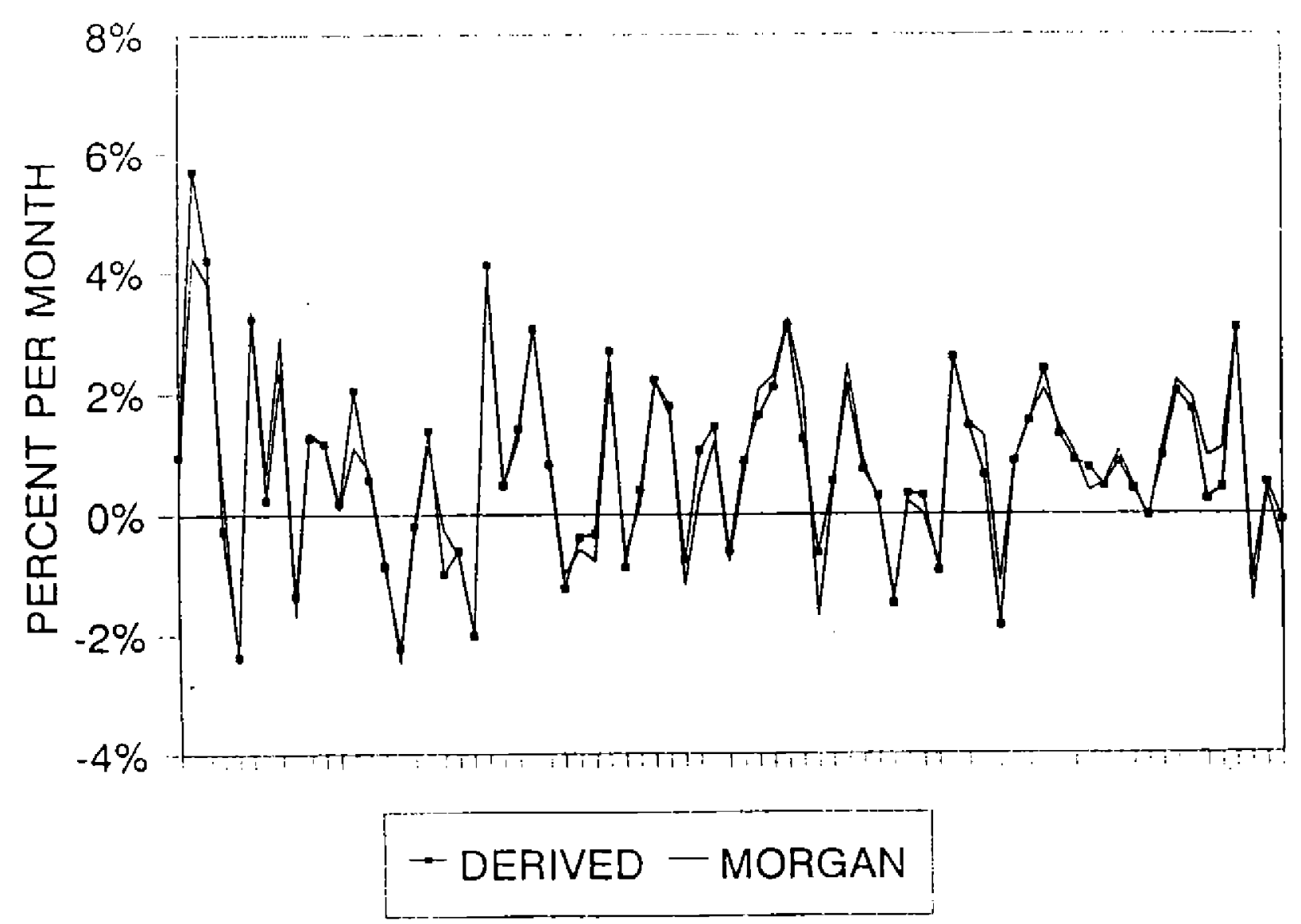

